\title{
Trade facilitation and its effects on Chile's bilateral trade between 2006 and 2014
}

\author{
Darcy Fuenzalida-O’Shee, Bárbara Valenzuela-Klagges \\ and Alejandro Corvalán-Quiroz
}

\begin{abstract}
This study analyses the effects of trade facilitation on Chilean exports in 2006-2014. It reviews evidence and studies on trade facilitation and its effects, mainly in South America; and it analyses Chile's export basket. An extended gravity model is then estimated for Chile's bilateral trade flow with 89 countries, to measure the effect of trade facilitation during the period analysed. The estimation is performed using static panel data with fixed, random and dynamic effects. The key results show that the estimation that best describes Chile's export behaviour is that which uses static panel data with random and dynamic effects and two lags of the dependent variable (exports). They show that per-container export costs have a negative effect on this trade flow.
\end{abstract}

\section{Keywords}

Trade liberalization, trade facilitation, imports, exports, costs, trade policy, bilateral trade agreements, trade statistics, Chile

\section{JEL classification}

F140, F150, F170

\section{Authors}

Darcy Fuenzalida-O'Shee is Dean of the Department of Commercial Engineering, Universidad Técnica Federico Santa María, Chile. Email: darcy.fuenzalida@usm.cl.

Bárbara Valenzuela-Klagges is a research fellow at the Institute of International Economics, Universitat Jaume I, Spain. Email: barbara.valenzuelak@usm.cl.

Alejandro Corvalán-Quiroz is an academic in the Department of Industry and Economics of the Faculty of Engineering, Universidad de Playa Ancha, Chile. Email: alejandro. corvalan@upla.cl. 


\section{Introduction}

A successful trade liberalization or integration process is founded on a country's capacity to move goods across borders reliably, quickly and at low cost. Although the cost of land, air or maritime transport, together with tariffs or customs procedures and logistic services, do not change the theoretical foundations of comparative advantage or the benefits of international trade, they can distort the movement of goods or services and influence the direction of trade, the terms of trade, agreements between countries and global competitiveness. Accordingly, transaction costs may differ according to efficiency, exporter integrity, and the public and private entities that participate in the export-import operation (OECD, 2003).

Jaén (2010) argues that efficient transport and logistic services have emerged as strategic elements of trade facilitation in explaining market access: "Trade facilitation means providing a more predictable, secure and efficient international trading environment, through the simplification, standardization and harmonization of administrative formalities" (Jaén, 2010, p. 108). Helble, Shepherd and Wilson (2007) add that the gains of greater predictability obtained from trade facilitation can be perceived in terms of falling trade costs and increasing domestic gains.

A variety of studies recognize that trade facilitation measures, including logistics systems in general, have a positive effect on countries' trade flows and, hence, on their productivity (Batra, Kaufmann and Stone, 2003; Wilson, Man and Otsuki, 2003; Engman, 2005; Nordas and others, 2006; Wilson, 2007; Jean-François and others, 2007; Echeverría, 2007; Hummels, 2007; Iwanow and Kirkpatrick, 2007; Martínez-Zarzoso and Márquez-Ramos, 2008; Servín, 2008; Castro, 2010; Djankov, Freund and Pham, 2010; Portugal-Pérez and Wilson, 2012; Moïsé and Sorescu, 2013; Cordero, 2014; Jordaan, 2014; Sant'Anna and De Souza, 2014; Zaki, 2015). Djankov, Freund and Pham (2010) estimated that an additional day's pre-shipment delay would reduce trade by at least $1 \%$. The Organization for Economic Cooperation and Development (OECD) (Wilson, 2007) notes that countries with lower transaction costs have experienced a larger increase in their gross domestic product (GDP) resulting from an increase in their manufactured exports. Moreover, small reductions in transaction costs significantly increase trade flows. Jean-François and others (2007) concur with this and suggest that developing countries can benefit more from world trade by applying trade facilitation measures and logistics systems; and they recommend upgrading transport infrastructure and implementing information technologies in customs. A study by Iwanow and Kirkpatrick (2007) concludes that a 10\% increase in trade facilitation would boost exports by about 5\%. Martínez-Zarzoso and Márquez-Ramos (2008) note that trade flows can be increased by reducing transport costs and the number of days needed to conduct trade. Moïsé and Sorescu (2013) find that supplying trade information, simplifying and harmonizing documentation and automating procedures has a major impact on the volumes and costs of a country's trade. Jordaan (2014), in a study focused on South Africa, concludes that improving the customs environment of the importing country provides greater gains in terms of increased trade flows, followed by improvements to the regulatory environment and national infrastructure. Sant'Anna and De Souza (2014) analyse Brazilian foreign trade and confirm that, if trade facilitation increases, so do Brazilian exports. Zaki (2015) shows that a multitude of trade facilitation variables, including the Internet, bureaucracy and corruption, affect import and export transaction times, and conclude that trade facilitation and liberalization are complements rather than substitutes.

In view of the evidence, Moreira and others (2013) consider it worrying that policymakers and researchers in Latin America do not consider the distributive dimension of trade costs arising from trade facilitation. Given the foregoing and the interest in analysing Chilean foreign trade in the global and specific context of trade costs, this study aims to analyse the effects of trade facilitation on Chilean exports between 2006 and 2014. 
To that end, the evidence and studies on trade facilitation and its effects in South America will be reviewed, and Chile's export patterns will be analysed, to gain an understanding of the current reality and the opportunities that exist to benefit from a reduction in the domestic costs arising from the export-import process. Subsequently, an extended gravity model will be estimated for Chile's bilateral foreign trade flows with 89 countries, to measure the effect of trade facilitation during the period analysed. This estimation will use static panel data with fixed, random and dynamic effects.

Recently, there has been an increase in the number of articles in which the gravity model is applied to determine export behaviour, which, directly and significantly, include Chile or the Southern Cone countries, the Southern Common Market (MERCOSUR) or the Andean Community (CAN) (Durso and Ochoa, 2003; Giacalone, 2003; Kamil and Ons, 2003; Martínez-Zarzoso and Nowak-Lehmann, 2003; Nicita, Olarreaga and Soloaga, 2003; Vallejo and Aguilar, 2004; Cárdenas and García, 2004; Lewer and Sáenz, 2004; Martínez-Zarzoso and Suárez-Burguet, 2004; Lara and Soloaga, 2005; López and Fernando, 2005; Sandberg, Seale and Taylor, 2006; Sá Porto and Azzoni, 2007; Serrano and Pinilla, 2008; Valenzuela-Klagges, 2011; Ramos-Martínez and others, 2012; Álvarez, Fischer and Natera, 2013; Florensa and others, 2013; Bacaria-Colom, Osorio-Caballero and Artal-Tur, 2013; Hernández, 2014; Valenzuela-Klagges and Espinoza-Brito, 2015). Several of these studies use cross -section data to apply this model; but nowadays there is a tendency to estimate the gravity model using static and panel data with fixed or random effects (De Souza and Burnquist, 2011, and Sant' Anna and De Souza, 2014) and dynamic effects. Nonetheless, there are still few studies that aim to determine the effects of trade facilitation on South American trade, and there are no published studies for the specific case of Chile.

The aim of this study is to contribute to scientific debate by considering current problems in Latin America (World Bank, 2013a and 2013b). The main results confirm that the estimation of static panel data with random and dynamic effects with two lags in the dependent export variable is what best describes Chilean export and import behaviour; and it shows that per-container exports costs have a negative effect on this trade flow.

\section{Trade facilitation and the south american reality}

According to Izam (2001), trade facilitation affects a wide variety of fields concerned with international transactions in goods or services, and to the movement of capital and business persons. It covers issues such as customs procedures, technical and quality standards, sanitary and phytosanitary measures, transport (land, air, sea, lake, river and rail), customs valuation, infrastructure, intellectual property, trade-related services, taxation, rules of origin, freedom of transit, electronic transmission of trade data, attention provided to business personnel and passengers, customs procedures, transparency, control and simplification, electronic commerce, payment services and insurance on international transactions, and also tariff and non-tariff issues. Moreover, by relating trade facilitation to the modernization of customs and government agencies involved in border inspection, Echeverría (2007) extends the list by adding public-private partnerships, rapid access to information, efficient and integrated transport, and short and agile procedures.

Based on these thematic areas of trade facilitation, recent studies include Wilson, Otsuki and Man (2004); Shepherd and Wilson (2006); Helble, Shepherd and Wilson (2007); Márquez-Ramos and others (2007); Iwanow and Kirkpatrick (2009); Hesketh (2010); DjanKov, Freund and Pham (2010); Márquez-Ramos and others (2011); Zamora and Sierens (2014); Ueki (2015) and Shepherd (2016). These can be subdivided according to the following topics of study: 
- $\quad$ Road access routes and minimum connection distance. Shepherd and Wilson (2006) present a database corresponding to 138 cities in 27 countries in Europe and Central Asia. They show that the quality of road networks positively affects intraregional trade flows and that improving them could increase trade by $50 \%$.

- $\quad$ Costs of maritime transport and logistics services. Márquez-Ramos and others (2007 and 2011) show that a reduction in freight costs and low freight rates can boost exports. They also note that, the larger the size of a port, the lower the cost of freight; and, the larger the number of shipping lines that compete on a given route, the lower are freight charges. The study by Zamora and Sierens (2014) review customs, international transport and logistics services, and find that these three variables directly and significantly affect the logistical competitiveness of international trade.

- $\quad$ Tariff reduction. Hesketh (2010) suggests that a reduction in tariffs and non-tariff barriers to world trade may encourage greater use of low-carbon energy technology.

- $\quad$ Technology use. DjanKov, Freund and Pham (2010); Helble, Shepherd and Wilson (2007), and Wilson, Otsuki and Man (2004) consider the index of the availability of e-government services.

- $\quad$ Trade barriers generally. Ueki (2015) analyses the impact of trade costs on the propensity to export and the intensity of firms in Southeast Asia and Latin America. It uses World Bank enterprise surveys and concludes that trade barriers do not significantly affect the export intensity of the firms in question.

Since 2014, progress has been made in global trade facilitation with the signing of the Trade Facilitation Agreement by the member countries of the World Trade Organization (WTO). Moreover, Shepherd (2016) notes that the Asia-Pacific Economic Cooperation Forum (APEC) continues to focus on trade facilitation and suggests analysing countries that have achieved a sharp reduction in international transaction costs, such as Taiwan Province of China. The author identifies three general areas for improving trade facilitation in APEC-member countries: physical connectedness, institutional connectedness and connectedness among peoples.

Table 1 lists ten articles that describe the reality of Latin America and the Caribbean in recent years. Of these, nine highlight excessive documentation and inefficient customs procedures; eight suggest the need to renew and expand port, land and road infrastructure in general; four analyse public management and the need to introduce modernizing reforms that guarantee trade facilitation without undermining security; three raise concerns about the number of days of paperwork or shipment delays needed to export two highlight the need to implement information technologies; and one considers private management. There are no commercial facilitation studies focusing on Chile.

A total of 104 countries that have maintained export and import flows with Chile continuously throughout 2006-2014 were selected for analysis. Of these 33 belong to Europe, 18 to Africa, 15 to Asia, 13 to the Middle East, 13 to North America and the Caribbean, 9 to South America and 3 to Oceania. In 2010, these 104 countries required an average of seven documents to import (see figure 1, which display 132 countries, including the 104 covered by this study). Chile was below the average, with six documents. Countries requiring fewer import-export documents include France, with two, Sweden and the Republic of Korea, with three, and Canada, with four. Cameroon and Kazakhstan (12), Russia (11), and Cambodia, Laos, Mozambique, Paraguay and Puerto Rico (10) are the countries that required the most import documents (World Bank, undated). Between 2012 and 2014, Chile has led the way in South America by cutting the number of required export documents to five. In contrast, the Bolivarian Republic of Venezuela and Paraguay both require nine. 
Table 1

Review of evidence in Latin American and Caribbean countries

\begin{tabular}{|c|c|c|c|}
\hline Author & Year & Countries in the study & Conclusions and suggestions \\
\hline $\begin{array}{l}\text { Batra, Kaufmann } \\
\text { and Stone }\end{array}$ & 2003 & Latin America & $\begin{array}{l}\text { The average time needed to complete an export or import process in Latin America } \\
\text { ranges from } 2 \text { to } 48 \text { days, compared to 1-24 days in other countries. }\end{array}$ \\
\hline $\begin{array}{l}\text { Ueki, Tsuji } \\
\text { and Cárcamo }\end{array}$ & 2005 & Latin America & $\begin{array}{l}\text { Burdensome trade procedures constitute considerable barriers for small and medium- } \\
\text { sized enterprises (SMEs) wishing to export their products. Inefficient handling of trade } \\
\text { documents supervised by government departments raises the cost of international trade. } \\
\text { The following recommendations are made to the region: create a network of researchers } \\
\text { to observe SMEs; provide distance education on trade and industry; form virtual } \\
\text { conglomerates; build commercial telecommunications infrastructure; unify technological } \\
\text { standards and information and communications technology (ICT) security, and adopt } \\
\text { trade facilitation measures. }\end{array}$ \\
\hline Nordas and others & 2006 & Dominican Republic & $\begin{array}{l}\text { Recognizes the importance of logistics systems in general and trade facilitation } \\
\text { measures in particular. }\end{array}$ \\
\hline Servín & 2008 & $\begin{array}{l}\text { Paraguay and } \\
\text { European Union }\end{array}$ & $\begin{array}{l}\text { The study recommends forging commitments to promote mechanisms that facilitate } \\
\text { foreign trade between Paraguay and the European Union, in particular to modernize ports, } \\
\text { develop ICTs and simplify and expedite customs procedures. }\end{array}$ \\
\hline Castro & 2010 & $\begin{array}{l}\text { Central America } \\
\text { and Panama }\end{array}$ & $\begin{array}{l}\text { The following problems are highlighted: excessive time and inspections needed to obtain } \\
\text { special permits, limited institutional support, problems in the training of customs } \\
\text { personnel, excessive procedures and systems, and infrastructure shortcomings. As part } \\
\text { of the improvement actions, emphasis is placed on the need to implement electronic } \\
\text { transmission systems and review procedures to simplify bureaucracy. In addition, } \\
\text { recommendations are made to strengthen the institutions supporting MSMEs. }\end{array}$ \\
\hline Barbero & 2010 & South America & $\begin{array}{l}\text { Priority actions are identified to improve trade facilitation: increase the provision of basic } \\
\text { infrastructure and infrastructure services targeted more directly on logistics; improve } \\
\text { services provided by exclusively the State, particularly customs and para-customs } \\
\text { management; improve the performance of private companies, including training for } \\
\text { smaller firms, and promote quality policies in logistics performance. }\end{array}$ \\
\hline Stark & 2011 & $\begin{array}{l}\text { El Salvador } \\
\text { and Guatemala }\end{array}$ & $\begin{array}{l}\text { This study highlights the need to formulate a strategy of international engagement that } \\
\text { affords consistency to programmes and actions within a long-term country vision, shared } \\
\text { by the main national actors. This strategy must be based on innovation and the } \\
\text { permanent creation of new and quality goods and services, as well as productivity } \\
\text { growth. Trade facilitation measures need to be included in these processes. }\end{array}$ \\
\hline $\begin{array}{l}\text { Fuentes } \\
\text { and Del Castillo }\end{array}$ & 2012 & Mexico & $\begin{array}{l}\text { The results show that the proposed tariff reduction policy does not have a significant } \\
\text { effect on economic growth or on the distribution of income across social groups. } \\
\text { The tariff reduction policy only implies a change in the components of the trade balance } \\
\text { and in the composition of employment. }\end{array}$ \\
\hline Cordero & 2014 & $\begin{array}{l}\text { CARICOM } \\
\text { and Central America }\end{array}$ & $\begin{array}{l}\text { Complementarity between Central America and the Caribbean Community (CARICOM) } \\
\text { is feasible thanks to productive specialization; but access routes need to be created } \\
\text { to maintain competitiveness. It is also necessary to increase trade facilitation to reduce } \\
\text { the costs and time of import-export processes. }\end{array}$ \\
\hline Cortes & 2014 & Colombia & $\begin{array}{l}\text { Colombia is not a trade-competitive country because of its obsolete logistics organization, } \\
\text { mainly in aspects related to infrastructure, traceability, the customs regime, corruption } \\
\text { and security, which increases export costs. }\end{array}$ \\
\hline
\end{tabular}

Source: Prepared by the authors.

In the 104 countries selected for this study, the average cost of exporting a container was US\$1,092.00 in 2010 (see figure 2). Chile was below the average, with a cost of US\$ 745. Asian countries are among those with the lowest per-container export cost, especially Singapore (US\$ 456), Malaysia (US\$ 450) and China (US\$ 500), while the countries with the highest per-container export cost are Kazakhstan (US\$3,005), Zambia (US\$2,664) and the Bolivarian Republic of Venezuela (US\$ 2,590). In 2013 and 2014, the per-container cost in Singapore was further reduced to US\$ 440, while the Bolivarian Republic of Venezuela and Zambia saw considerable increases to US\$3,490 and US\$ 6,369, respectively. 
Figure 1

Number of documents required to import in 132 countries, 2010a

(Number of documents and countries)

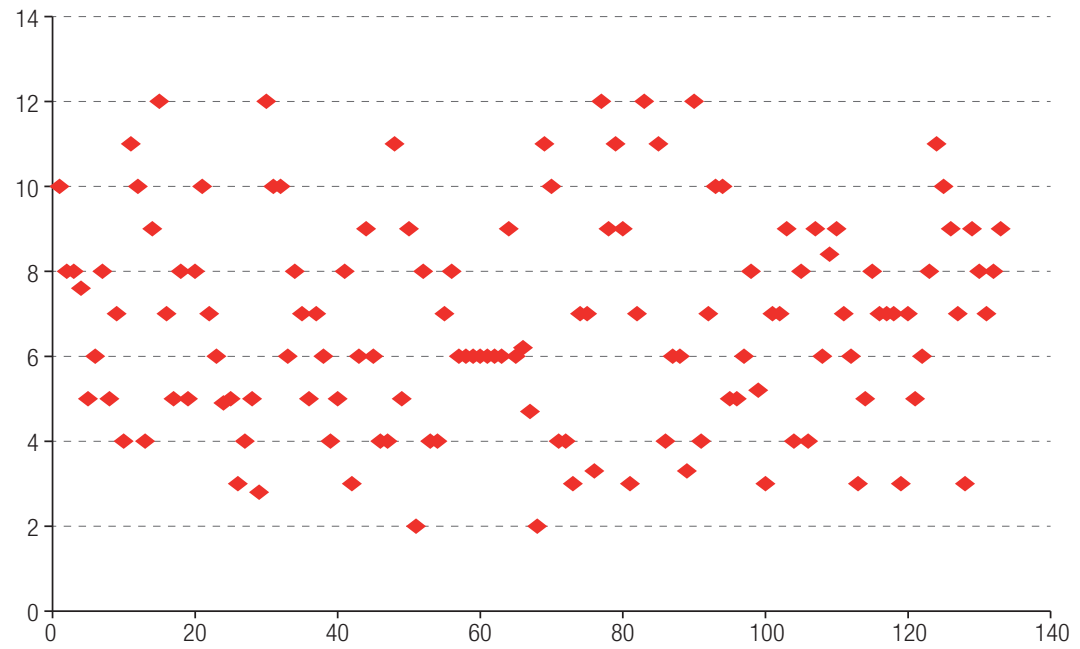

Source: Prepared by the authors, on the basis of datafrom World Bank, "World Bank Open Data” [online] https://data.worldbank.org/. a Countries that maintained export and import flows with Chile continuously throughout 2006-2014.

Figure 2

Export costs in 132 countries, $2010^{a}$

(Dollars and countries)

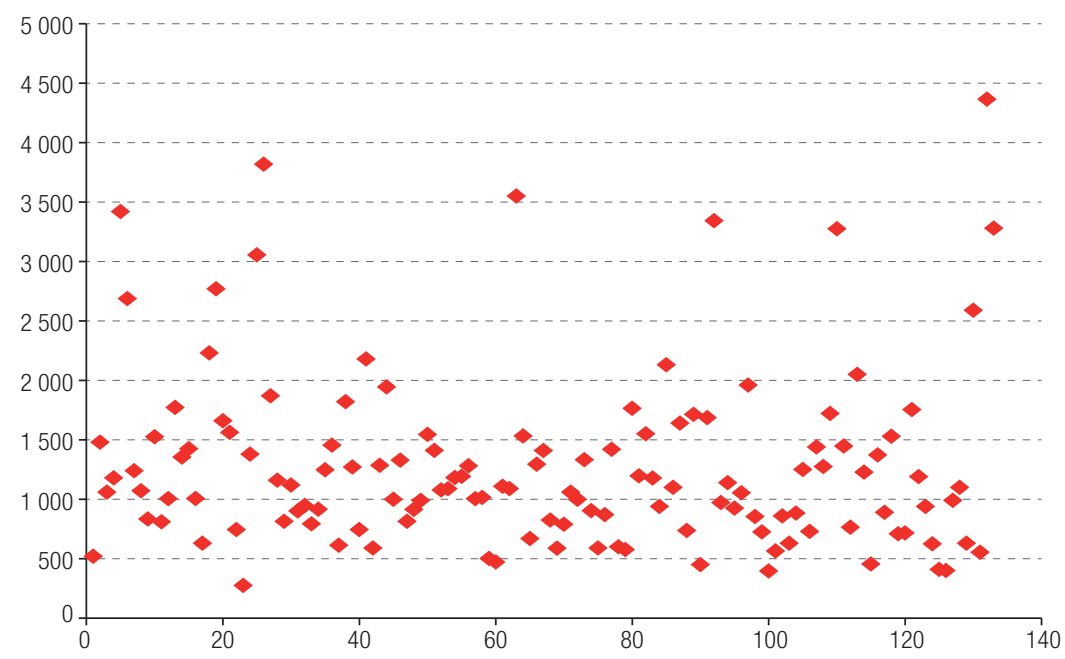

Source: Prepared by theauthors, on the basis of datafrom World Bank, "World Bank Open Data" [online] https://data.worldbank.org/. a Countries that maintained export and import flows with Chile continuously throughout 2006-2014.

The average export cost in the Southern Cone countries rose from US\$ 966.67 per-container in 2005 to US\$1,772.9 in 2014, driven particularly by costs in the Bolivarian Republic of Venezuela, Brazil and Colombia. In 2005, these countries had the lowest per-container export costs, along with Peru; but in 2007, 2008 and 2009, costs rose drastically. In particular, between 2012 and 2014, there was a significant increase in per-container export costs in the Bolivarian Republic of Venezuela (US\$3,490), Brazil (US\$ 2,414), Colombia (US\$2,355), Paraguay (US\$1,850) and Argentina (US\$ 1,650). Chile and Peru have succeeded in maintaining the lowest costs per-container in South America: in 2014, the average cost was US\$ 890 in Peru and US\$ 980 in Chile. 
Figures 3 and 4 show the maximum applied tariff in the countries of South America in 2009 and 2014 (no information is available for the Bolivarian Republic of Venezuela in 2009). In 2014, the Bolivarian Republic of Venezuela, Colombia and Ecuador are the countries with the highest applied tariffs, of 160\%, 98\% and 86\%, respectively (WTO/ITC/UNCTAD, 2015). Chile and Peru have the lowest maximum applied tariffs in 2009 and 2014; and Chile has the lowest indicator of all: 13\% in 2009 and 6\% in 2014. The maximum applied tariffs in 2014 in the South American countries are below the average of those applied worldwide (175.3\%), as stated in the report World Tariff Profiles (WTO/ITC/ UNCTAD, 2015). The countries with the highest applied tariffs are Egypt, Fiji, Malaysia and Norway.

\section{Figure 3}

South America (9 countries): maximum applied tariff rate, 2009 (Percentages)

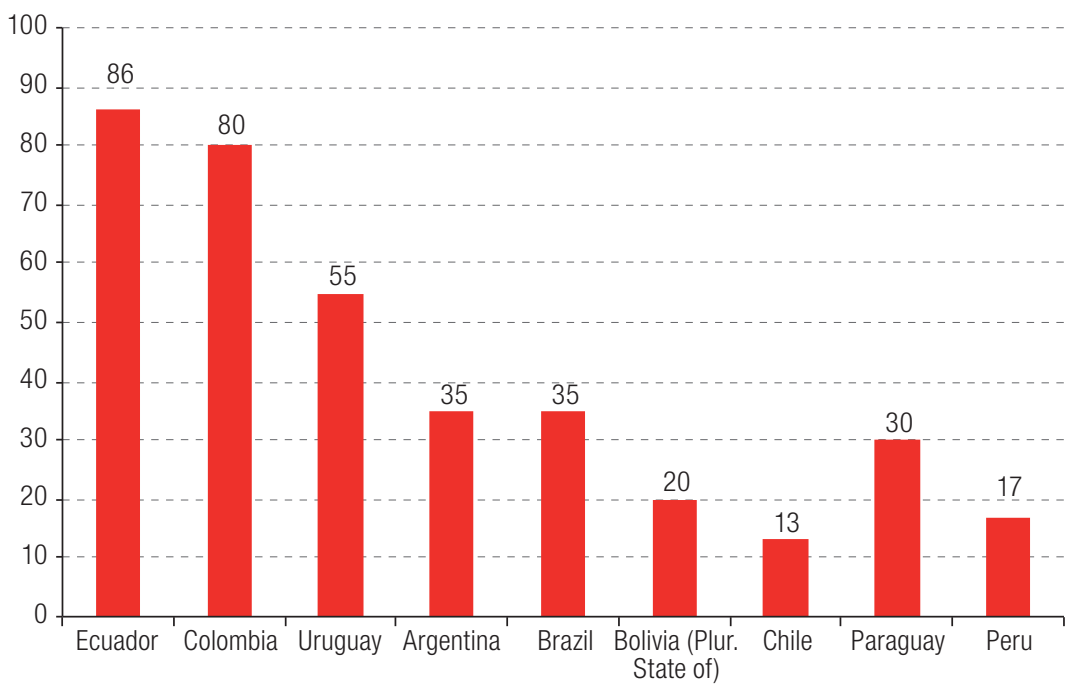

Source: Prepared by the authors, on the basis of data from World Trade Organization (WTO)/International Trade Centre (ITC)/ United Nations Conference on Trade and Development (UNCTAD), World Tariff Profiles, 2010 (UNCTAD/WTO/2010), Geneva, 2010.

Figure 4

South America (10 countries): maximum applied tariff rate, 2014 (Percentages and countries)

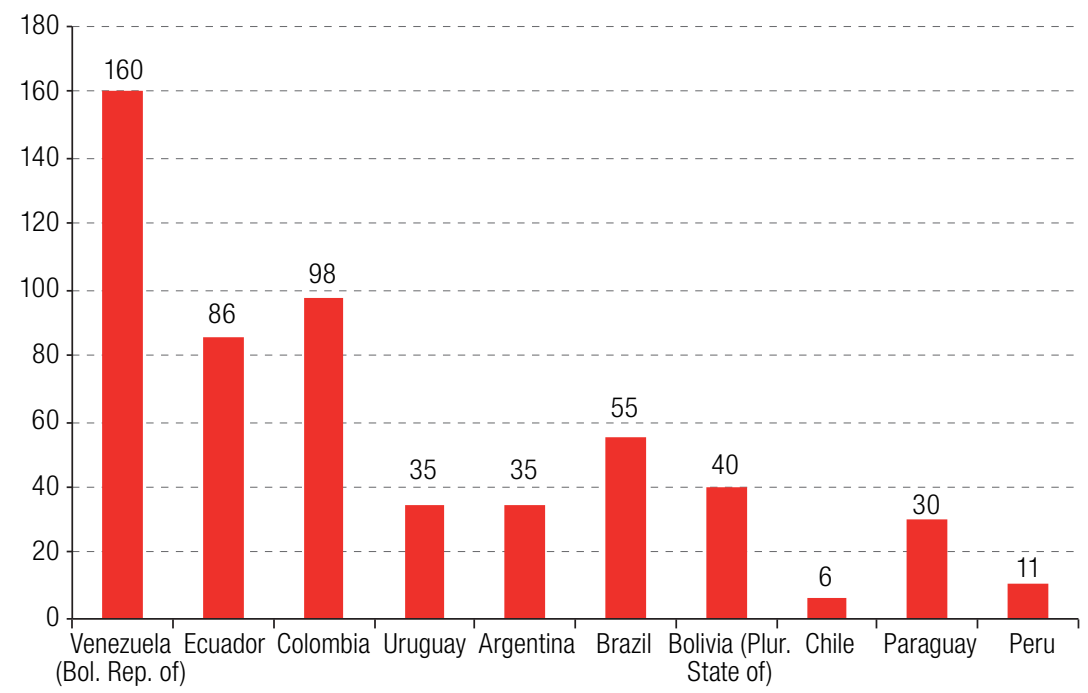

Source: Prepared by the authors, on the basis of data from World Trade Organization (WTO)/International Trade Centre (ITC)/ United Nations Conference on Trade and Development (UNCTAD), World Tariff Profiles, 2015 (UNCTAD/WTO/2015), Geneva, 2015. 


\section{Characteristics of the chilean export basket}

Table 2 lists the main categories of goods exported by Chile in 2006 and 2014. In recent years, the export basket has continued to be highly concentrated in copper and its derivatives, which represent $57 \%$ of total exports in 2006 and $51 \%$ in 2014. The drop in this percentage is probably a direct reflection of the fall in the real price of the product, since the real historical price of refined copper attained a level of 328.2 U.S. cents per pound in 2006, but had fallen to 299.3 cents in 2014 (Sociedad Nacional de Minería). ${ }^{1}$

Table 2

Chile: main exportable goods, 2006 and 2014

(Percentages of total)

\begin{tabular}{lcc}
\hline Exportable goods & 2006 & 2014 \\
\hline Cathodes and cathode sections & 28.84 & 23.02 \\
\hline Copper ores and concentrates & 20.45 & 22.2 \\
\hline Copper for refining & 4.98 & 3.91 \\
\hline Concentrates & 2.41 & 1.95 \\
\hline Others & 43.32 & 48.92 \\
\hline
\end{tabular}

Source: Prepared by the authors, on the basis of Latin American Integration Association (LAIA), "Estadísticas de comercio exterior", 2016 [online] http://consultawebv2.aladi.org/sicoexV2/jsf/comercio_exterior_item_arancelario.seam?cid=10711.

Table 3 reports the share of the main destinations for Chilean exports in 2006 and 2014. Market diversification remained poor during the period, although exports to China increased from 15.71 of the total in 2006, to $24.55 \%$ in 2014. If Chile's main export markets in 2014 are grouped by continent, Asia is the leading destination, accounting for just under $44.7 \%$ of the total.

Table 3

Chile: main destinations for exports, 2006 and 2014

(Percentages of total)

\begin{tabular}{lclc}
\hline Partner country & 2006 & Partner country & 2014 \\
\hline United States & 16.01 & China & 24.55 \\
\hline Japan & 10.81 & United States & 11.75 \\
\hline China & 8.84 & Japan & 10.46 \\
\hline Netherlands & 6.83 & Republic of Korea & 6.15 \\
\hline Republic of Korea & 6.09 & Brazil & 5.44 \\
\hline Italy & 5.03 & India & 3.47 \\
\hline Brazil & 4.94 & Netherlands & 2.9 \\
\hline Other & 41.45 & Others & 35.28 \\
\hline
\end{tabular}

Source: Prepared by the authors, on the basis of Latin American Integration Association (LAIA), "Estadísticas de comercio exterior", 2016 [online] http://consultawebv2.aladi.org/sicoexV2/jsf/comercio_exterior_item_arancelario.seam?cid=10711.

This reality of Chilean foreign trade, which is characterized by the extraction of natural resources for export mainly to China and other Asian countries, is replicated elsewhere in Latin America. Dingemans and Ross (2012) show that export growth in the Latin American countries has partly occurred on the intensive margin rather than extensively; so expansion towards new products and trade partners has been limited. Meller, Poniachik and Zenteno (2012) show that the international commodity price boom in 2011 and 2012 brought significant benefits to Latin American countries, however; and in relation to China: "The large increase in the commodity share" in the Latin American export basket has aroused fears of a return of the "natural resource curse" (Meller, Poniachik and Zenteno, 2012, p. 2).

1 http://www.sonami.cl/index.php?option=com_content\&view=article\&id=224\&ltemid=117. 
An analysis of the reality of Latin American countries, including Chile, shows that the extractive model used to participate in world trade has led to the exhaustion of economic growth and social development.

\section{Model specification}

This research builds an extended gravity model, using pool and static panel data with fixed, random and dynamic effects (Arellano-Bond and Arellano-Blundell), to analyse the effects of trade facilitation on Chilean exports between 2006 and 2014. The first authors to use the gravity model to analyse international trade were Tinbergen (1962), Pöyhönen (1963) and Linnemann (1966). In the studies by Anderson (1979), Bergstrand (1985) and Helpman and Krugman (1985), gravity equations were derived from international trade models based on product differentiation and increasing returns to scale; and rigorous theoretical support was provided. Mátyás (1997), Cheng and Wall (1999), Bayoumi and Eichengreen (1998), Breuss and Egger (1999) and Egger (2000) provide econometric specifications. In recent decades, the gravity model has been one of the most widely used to analyse international trade, migration or foreign investment flows, due to their properties, their theoretical and empirical support, and their flexibility and adaptability to different regional realities or to that of a particular country.

For this study, the extended linear gravity model will be specified by the following equation expressed in natural logarithm form:

$$
\begin{gathered}
\ln \left(E_{i j t}\right)=\beta_{0}+\mu_{1} \ln y_{i t}+\mu_{2} \ln y_{j t}+\xi_{1} \ln \text { Arancel }_{i t}+\xi_{2} \ln \text { Arancel }_{j t} \\
+\alpha_{1} \ln D_{i j}+\phi_{1} \ln \text { Doce }_{i t}+\phi_{2} \ln \text { Doci }_{j t}+\eta_{1} \ln \text { Cose }_{i t}+\eta_{2} \ln \text { Cosi }_{j t} \\
+\nu_{1} \ln T C E_{i t}+\sum_{k} \delta_{h} P_{i j}+u_{i j t}
\end{gathered}
$$

where: ${ }^{2}$

$i, j$ and $t$ represent the exporting country, importing country and year, respectively;

$E_{i j}$ represents the export flow from country $i$ to $j$;

$Y_{i, j}$ denote the real GNP of country $i$ and $j$, respectively;

Arancel $_{i}$, Arancel $_{j}$ represent the weighted average applied tariff rates of country $i$ and $j$ (in percentages); $D_{i j}$ is the geographical distance between the capitals of countries $i$ and $j$ in kilometres;

Doce is the number of documents required by the exporting country for an export;

Doci is the number of documents required by the importing country for an import;

Cose represents the per-container export cost, in dollars;

Cosi represents the per-container import cost, in dollars;

$T C E_{i}$ denotes the exporting country's effective exchange rate.

In addition, equation (1) includes dummy variables represented by $\sum_{h} \delta_{h} P_{i j}$ which assume the value 1 in the the event in question occurs or 0 otherwise. The individual dummies variables are as follows:

$F_{i j}: \quad$ common border between country $i$ and country $j$;

$I C_{i j}: \quad$ common language between country $i$ and country $j$;

\footnotetext{
2 The following databases will be used: Latin American Integration Association (LAIA) (www.aladi.org) - amounts exported from Latin American countries in millions of dollars FOB and amounts imported from non-Latin American countries in millions of dollars CIF; www.wcrl.ars.usda.gov/cec/java/lat-long.htm - distance in kilometers between the capitals of the countries under study; and World Bank, statistical data (http://datos.bancomundial.org/).
} 
NAFTA-CL: $\quad$ trade between Chile and the member countries of the North American Free Trade Agreement (NAFTA), namely the United States, Canada and Mexico;

MERCOSUR-CL: trade between Chile and the member countries of the Common Market of the South (MERCOSUR), namely Argentina, Brazil, Paraguay, Uruguay and, since 2014, the Bolivarian Republic of Venezuela;

China-Cl: $\quad$ trade between China and Chile;

UE-Cl: $\quad$ trade between Chile and member countries of the European Union (EU);

2006-2007: time variable representing the years 2006 and 2007;

2009: $\quad$ time variable that represents the year 2009, and

2013-2014: $\quad$ time variable representing the years 2013 and 2014.

Theoretically, the larger the real GNPs of the exporting and importing countries, the stronger the gravitational attraction between them; in contrast the greater the geographical distance, the less the attraction. The number of documents required to export and import, in conjunction with the per-container cost of exports and imports and tariff rates, are used to represent trade facilitation and quantify its effects on Chilean foreign trade. Chile's trade accords, along with its free trade agreements with the member countries of NAFTA, MERCOSUR, the EU and China, will make it possible to assess whether these agreements facilitate bilateral trade.

The exporter's effective exchange rate is included as a variable in the gravity equation to determine its potential impact on export volumes. According to Bernat (2015), to the extent that the cost structure of a country's production is light in non-tradable inputs, movements in the real exchange rate can be expected to have little influence on most of that country's exports.

A dummy variable representing a common border seeks to distinguish the border effects of trade with neighbouring countries from the rest of Chile's bilateral trade. This variable will also measure the majority use of land transport with these countries. Time dummy variables are included to capture temporary effects and events characteristic of those years, such as the subprime mortgage crisis in 2009 and the fall in copper prices in 2013 and 2014.

This study will include 89 countries that trade with Chile, classified by geographical area, as follows: 31 countries from Europe; 10 from Africa; 15 from Asia; 7 from the Middle East; 2 from North America; 11 from Central America and the Caribbean; 11 from South America, and 2 from Oceania. These countries accounted for $91 \%$ of Chile's export destinations during the study period. A few countries have been excluded owing to the small volume or absence of trade for one or more consecutive years in that period. The total number of observations per year is 178 , making a total of 1,602 observations.

Since a large sample of countries and years is generally used when applying a gravity model, some observations of the endogenous variables (such as export, import or total trade) have a zero value. To address the problem of zero observations in trade, Piani and Kume (2000), Zago de Azevedo (2001) and Wall (2003) have replaced them by small values (0.001) in the dependent variable (amount exported by the trading partners); and Eichengreen and Irwin (1998) and Wall (2003) have added 1 to all observations. Nonetheless, Santos-Silva and Tenreyro (2006) draw attention to a problem related to the analogy between Newtonian gravity and trade, since the gravitational force may be very small, but it is never 0 ; yet trade between several pairs of countries can indeed post zero values. An additional problem is the use of logarithms in the linear form of the gravity equation. Faced with this problem and the methods available to address it, the authors suggest that adding 1 to the dependent variable or using a Tobit estimator can produce inconsistent estimators. 
In this study, one of the recommendations made by Santos-Silva and Tenreyro (2006) was followed, and it was decided to use a sample of countries whose flow of bilateral trade with Chile did not record zero observations in the study period. For this, the export and import amounts were reviewed in detail and not in thousands of dollars; and trading partner countries with zero in the dependent variable, in one or more years, were excluded. Accordingly the sample was determined by 89 countries covering $91 \%$ of the total amount exported by Chile during the period under study. Equation (1) will be estimated using static panel data with random effects, where the intercept of the regression will be random $\left(\beta_{0}\right)$ and defined as $\beta_{0}=\beta+u_{1}$. In other words, instead of considering $\beta$ as a fixed intercept, it is projected as a random variable with mean value $\beta$ and a random deviation from the mean.

Equation (1) is adapted for estimation with fixed effects panel data, to give equation (2), in which all the fixed variables that are maintained throughout the study period are excluded. This estimate makes it possible to observe intersections of all pairs of trade partners, discarding a shared constant.

$$
\begin{gathered}
\ln \left(E_{i j t}\right)=\beta_{i j t}+\mu_{1} \ln y_{i t}+\mu_{2} \ln y_{j t}+\xi_{1} \ln \text { Arancel }_{i t}+\xi_{2} \ln \text { Arancel }_{j t} \\
+\phi_{1} \ln \text { Doce }_{t}+\phi_{2} \ln \text { Doci }_{t}+\eta_{1} \ln \text { Cose }_{t}+\eta_{2} \ln \text { Cosi }_{t}+\nu_{1} \ln T C E_{i t}+u_{i j t}
\end{gathered}
$$

where $\beta_{i j t}$ is a fixed number for each pair of trading partners.

Given the potential endogeneity of the phenomenon being studied, it is advisable to use panel data with dynamic effects. Arellano and Bover (1990) argue that one of the ways in which using a panel is positive and decisive with respect to a cross-sectional sample is the possibility of modelling dynamic responses with microdata: equations can be specified with lagged endogenous and exogenous variables, thereby making it possible to explain adjustment processes (Arellano and Bover, 1990, p. 5).

Equation (1) is adapted to perform the estimation with dynamic panel data (equation (3)).

$$
\begin{gathered}
\ln \left(E_{i j t}\right)=\beta_{0}+\beta_{1} \ln \left(E_{i j t-1}\right)+\beta_{1} \ln \left(E_{i j t-2}\right)+\mu_{1} \ln y_{i t}+\mu_{2} \ln y_{j t}+ \\
\xi_{1} \ln \text { Arancel }_{i t}+\xi_{2} \ln \text { Arancel }_{j t}+\alpha_{1} \ln D_{i j t}+\phi_{1} \ln \text { Doce }_{t}+\phi_{2} \ln \text { Doci }_{t} \\
+\eta_{1} \ln _{\text {Cose }}+\eta_{2} \ln \text { Cosi }_{t}+\nu_{1} \ln T C E_{i t}+\sum_{k} \delta_{h} P_{i j}+u_{i j t}
\end{gathered}
$$

where $E_{i j t-1}$ represents the first lag of the dependent variable and $E_{i j t-2}$ denotes the flow of exports from country $i$ to country $j$. This equation will be estimated using the Arellano-Bond and Arellano-Blundell techniques.

\section{Results}

Table 4 shows the results obtained using static panel data with random and fixed effects (equations (1) and (2), respectively), and with dynamic effects (equation (3), Arellano-Bond and Arellano-Blundell). The Hausman test is applied to observe the differences between the fixed and random effects coefficients, and Prob $>\chi^{2}=0.051$ is obtained. This confirms that the random effects method is superior to the fixed effects method in explaining Chilean exports of manufactured goods to the countries in the sample. Nonetheless, the coefficient of determination obtained in the estimation with random effects $(0.77)$ is quite high. The Durbin, Wu and Hausman test detected endogeneity, so it is better to use the dynamic panel. 
Table 4

Results of the estimation of equations (1), (2) and (3)

\begin{tabular}{|c|c|c|c|c|}
\hline Variables & $\begin{array}{l}\text { Fixed effects } \\
\text { (equation (2)) }\end{array}$ & $\begin{array}{l}\text { Random effects } \\
\text { (equation (1)) }\end{array}$ & $\begin{array}{l}\text { Dynamic effects } \\
\text { (equation (3), } \\
\text { Arellano-Bond) }\end{array}$ & $\begin{array}{l}\text { Dynamic effects } \\
\text { (equation (4), } \\
\text { Arellano-Blundell) }\end{array}$ \\
\hline $\operatorname{Ln}(\operatorname{Exp}-1)$ & & & $0.23(0.06)^{\star \star \star}$ & $0.36(0.06)^{\star * \star}$ \\
\hline $\operatorname{Ln}(\operatorname{Exp}-2)$ & & & $-0.14(0.03)^{\star \star \star}$ & $-0.11(0.03)^{\star \star \star}$ \\
\hline Ln (GNP exporting country) & & $1.57(0.08)^{\star \star \star}$ & $3.0(0.5)^{\star \star \star}$ & $0.87(0.2)^{\star \star \star}$ \\
\hline Ln (GNP importing country) & $2.5(0.2)^{\star \star \star}$ & $1.19(0.08)^{\star \star \star}$ & & \\
\hline Ln (geographic distance) & & & $-6.5(1.2)^{\star \star \star}$ & \\
\hline \multicolumn{5}{|l|}{$\operatorname{Ln}(D O C E)$} \\
\hline \multicolumn{5}{|l|}{$\operatorname{Ln}(\mathrm{DOCl})$} \\
\hline $\operatorname{Ln}($ export cost) & & $-1.2(0.18)^{\star \star \star}$ & $-1.1(0.42)^{\star \star \star}$ & $-1.0(0.4)^{\star \star}$ \\
\hline \multicolumn{5}{|l|}{ Ln (import cost) } \\
\hline Ln (export tariff) & & $-0.1(0.05)^{\star}$ & & \\
\hline \multicolumn{5}{|l|}{ Ln (import tariff) } \\
\hline \multicolumn{5}{|l|}{ Ln (effective exchange rate) } \\
\hline \multicolumn{5}{|l|}{ Common border } \\
\hline Common language & & $2.93(0.32)^{\star \star \star}$ & & \\
\hline NAFTA-Chile agreement & & & & $24.6(11.06)^{\star}$ \\
\hline MERCOSUR-Chile agreement & & $1.77(0.6)^{\star \star \star}$ & & $-19.8(7.7)^{\star \star}$ \\
\hline \multicolumn{5}{|l|}{ CHINA-Chile agreement } \\
\hline \multicolumn{5}{|l|}{ EU-Chile agreement } \\
\hline Years 2006 and 2007 & & $-0.39(0.07)^{\star \star \star}$ & & \\
\hline Year 2009 & & $-0.22(0.08)^{\star \star \star}$ & & $-0.36(0.06)^{\star \star \star}$ \\
\hline \multicolumn{5}{|l|}{ Years 2013 and 2014} \\
\hline Constant & $-54.4(6.0)^{\star \star \star}$ & $-51.9(3.1)^{\star \star \star}$ & & $-14.4(5.4)^{\star \star \star}$ \\
\hline $\mathrm{R}^{2}$ & 0.18 & 0.77 & & \\
\hline Number of observations & 1602 & 1602 & 1602 & 1602 \\
\hline
\end{tabular}

Source: Prepared by the authors.

Note 1: Values corrected for heteroscedasticity.

Note 2: Significance level: ${ }^{\star \star \star}=0 \%$ error; ${ }^{\star \star}=0 \%<\mathrm{P} \leq 2.5 \%$; ${ }^{*}=2.5 \%<\mathrm{P} \leq 5 \%$.

Note 3: Standard errors in parentheses.

Table 4 reports the results obtained when estimating equation 3 for panel data with dynamic effects and two lags of the dependent variable, using the Arellano-Bond and Arellano-Blundell techniques. The coefficients estimated through panel data with dynamic effects (equation (3), table 4) show that endogeneity decreases and is consistent with the relevant theory. The results indicate that the first lag of the dependent variable is positive and significant, while the second lag is negative and significant.

The estimates through random and dynamic effects (Arellano-Bond and Arellano-Blundell) show that the coefficient of the exporting country's real GNP is positive and significant, while the coefficient on export costs is negative and significant.

The dynamic effect using the Arellano-Blundell technique significantly reduces endogeneity. The NAFTA-Chile agreement is seen to positively affect Chile's bilateral trade, while the agreement between MERCOSUR and Chile has negative effects. The subprime mortgage crisis is shown to have had a negative effect on Chile's bilateral trade. There is no significant effect from the variables representing the number of export and import documents required, import costs, tariffs in the exporting and importing countries, the effective exchange rate, a common border, a common language, the China-Chile agreement, the EU-Chile agreement, and the dummy time variables for 2006 and 2007, and 2013 and 2014. 


\section{Conclusions and recommendations}

As Chile is embedded in the Latin American reality, the effects of trade facilitation on its exports and imports in 2006-2014 were analysed by firstly reviewing case studies and evidence on trade facilitation in Latin American countries, including Chile, and comparing with countries from other continents. Statistical data on trade facilitation in Chile and its main trading partners were then analysed in terms of the documents required to import and export, per-container export and import costs, and maximum applied tariff rates. The Chilean export basket and its implications were also analysed. Lastly, a gravity model was specified and applied using panel data to measure the effects of trade facilitation on Chile's exports.

Studies focused on Latin America highlight excessive export and import documentation, the high costs involved in exporting a container, the inefficiency of logistics services and customs procedures, inadequate port infrastructure and the ponderous response of public institutions in general, which affect the price of the exported good and undermine competitiveness in the destination country. Evidence from recent years shows a gradual increase in per-container export costs in Latin America, mainly in the Bolivarian Republic of Venezuela, Brazil and Colombia. In contrast, Chile and Peru are recognized as the only countries in which low export costs per-container have been maintained. Nonetheless, while these are below the world average, they are still twice those observed in Asian countries.

This reality calls for reforms to rationalize customs procedures and target public and private investment on projects that increase or improve port, land and road infrastructure to enhance the region's comparative advantages and improve its competitiveness. This would generate increased exports of traditional and non-traditional goods in South America. Based on the evidence reported by Iwanow and Kirkpatrick (2007), Jean-François and others (2007) and Zaki (2015), reducing bureaucracy and levels of perceived corruption, in conjunction with the use technological tools, would reduce the time it takes to import and export, particularly the number of days' bureaucracy in Latin America. This would lower per-container export costs and enhance the competitiveness of regional exports. Several studies, such as Márquez-Ramos and others (2007 and 2011), which focus on the cases of Spain and Latin America, argue that reducing per-container export costs and freight charges in the transportation chain helps to boost volumes exported.

Chile's exports remain relatively undiversified, in terms of both the goods exported and the destination markets. Heavy dependence on copper and its derivatives, as the main and predominant export products, constitutes a potential vulnerability in trade and the national economy that needs to be addressed in the short term. This dependence probably discourages the application of trade facilitation measures, which hinders the diversification of exportable goods and also conditions export behaviour in the subsequent year. Several studies (Wilson, 2007; Moreira and others, 2013, for example) show that the lower the export costs, the greater the production of manufactured goods, and this evidence should be included in the debate on Chile's public policies and economic sectors which aim to promote exports with greater technological content.

When estimating the gravity model using static panel data with fixed and random effects, the results confirm that it is preferable to do the calculation using panel data with random and dynamic effects with two lags in the dependent variable, although the estimation using dynamic panel data (Arellano-Blundell) best describes Chilean export behaviour and is consistent with the evidence and theories that have been put forward on trade facilitation. These results reveal the following:

- $\quad$ The greater the previous year's exports, the smaller the exports of two years earlier. This indicates that Chile's export and import behaviour is dynamic and fluctuating, with negative effects every two years, but with an upward trend. Another finding is that, the higher the real GNP of the exporting country and the lower the per-container export cost, the greater the trade flow between Chile and its trading partners. The coefficient representing the impact of the per-container export 
cost is larger than the coefficients on the lagged variables and the exporting country's real GNP. Accordingly, the per-container export cost needs to be reduced to facilitate Chile's trade. This means confronting the reality of Chilean ports and investing in infrastructure and port capacity, which are very limited, improving logistics services, carrying out infrastructure projects that optimize land and highway connections, and cutting waiting times in ports and in public and private warehouses.

- The average tariff rates of the importing and exporting countries do not affect the trade flow between Chile and the sample countries. A possible explanation for this is that Chile's weighted-average tariff has been declining and was already very low during the study period. According to data from the Santiago Chamber of Commerce (CCS, 2016), Chile's effective import tariff dropped from $8 \%$ to $2.1 \%$ between 1999 and 2004, and then to $1.2 \%$ in 2009, where it has remained until 2015.

- $\quad$ The Free Trade Agreement (FTA) signed between the NAFTA member countries and Chile has facilitated trade, while the economic complementation agreement with MERCOSUR member countries has been negative for the trade flow between Chile and those countries. The other agreements, such as those concluded with China and the EU, do not show significant effects during the period analysed. These results show the importance of the FTAs signed with NAFTA members, the first of which was Canada (1996), then Mexico (1998) and, lastly, the United States (2003). This suggests that the recent Pacific Alliance formed by Chile, Colombia, Mexico and Peru could facilitate Chilean foreign trade in the coming decades. In contrast, the integration of Chile with the member countries of MERCOSUR is becoming counterproductive for Chile's bilateral trade. According to García (2013), the Pacific Alliance can be seen as a new stage of Latin American integration, which is departing from models that are more ideological than integrationist and characteristically closed, as is the case of MERCOSUR. The lack of significance of the coefficient on the China-Chile FTA may reflect the fact that it is a recent agreement, only signed in October 2006, so its effect on bilateral trade cannot yet be discerned empirically. It may also be because copper and its derivatives are Chile's main export to China, so it would not be the agreement that deviates or creates trade, but the exporting country's GNP, which in this study displays a positive and significant coefficient.

- $\quad$ The variables representing geographical distance, common border and common language do not influence the Chilean export-import process, probably because Chile's export-import trade is concentrated in Asian countries, which implies a great geographical distance and different languages.

- The real effective exchange rate of the exporting country appears not to be significant, which confirms that Chilean exports are not based on technological intensity but on natural resource extraction. This result is consistent with the claim made in Bernat (2015).

- The subprime mortgage crisis had a negative effect on Chile's bilateral trade, thereby confirming the vulnerability of the country's exports, especially owing to the reliance on copper and its derivatives.

Although the variable representing the number of documents required to import and export did not prove significant in the estimated model, their number should be reduced further, to increase the provision of basic infrastructure and infrastructure services, as suggested by Barbero (2010), with the aim of reducing per-container export costs, increasing public funds and encouraging private investments that upgrade the quality of domestic and international road networks.

Chilean ports need to be expanded to reduce freight costs, as proposed by Márquez-Ramos and others (2011); and, according to Salgado and Cea (2012), the ports of lquique, San Vicente and Valparaíso need strengthening since they provide exporters with greater access to logistics 
chains better suited to their products. Feasibility studies should be performed for new port projects, since the southern ports are easier to access from the sea and could attract more shipping lines to that area.

Lastly, medium-term planning should be designed to guarantee the national overland connection (especially railways), review the staffing of customs services, and consider programmes of training and support for public- and private-sector personnel involved in the logistics process, while promoting quality policies on logistical performance.

\section{Bibliography}

Álvarez, I., B. Fischer and J. M. Natera (2013), "Internationalization and technology in MERCOSUR", CEPAL Review, No. 109 (LC/G.2556-P), Santiago, Economic Commission for Latin America and the Caribbean (ECLAC). Anderson, J. (1979), "A theoretical foundation for the gravity equation", American Economic Review, vol. 69, No. 1, Nashville, American Economic Association.

Arellano, M. and O. Bover (1990), "La econometría de datos de panel", Investigaciones Económicas (Segunda Época), vol. 14, No. 1, Madrid, SEPI Foundation.

Bacaria-Colom, J., M. Osorio-Caballero and A. Artal-Tur (2013), "Evaluación del Acuerdo de Libre Comercio México-Unión Europea mediante un modelo gravitacional", Economía Mexicana. Nueva Época, No. 1, Mexico City, Economic Research and Teaching Centre.

Barbero, J. A. (2010), "Freight logistics in Latin America and the Caribbean: an agenda to improve performance", Technical Notes, No. IDB-TN-103, Washington, D.C., Inter-American Development Bank (IDB).

Batra, G., D. Kaufmann and A. Stone (2003), Investment Climate Around the World: Voices of the Firms from the World Business Environment Survey, Washington, D.C., World Bank.

Bayoumi, T. and B. Eichengreen (1998), "Exchange rate volatility and intervention: implications of the theory of optimum currency areas", Journal of International Economics, vol. 45, No. 2, Amsterdam, Elsevier.

Bergstrand, J. (1985), "The gravity equation in international trade: some microeconomic foundations and empirical evidence", The Review of Economics and Statistics, vol. 67, No. 3, Cambridge, Massachusetts, The MIT Press.

Bernat, G. (2015), "Tipo de cambio real y diversificación productiva en América del Sur", Studies and Perspectives series, No. 43 (LC/L.4031), Santiago, Economic Commission for Latin America and the Caribbean (ECLAC).

Breuss, F. and P. Egger (1999), "How reliable are estimations of East-West trade potentials based on cross-section gravity analyses?, Empírica, vol. 26, No. 2, Springer.

Cárdenas, M. and C. García (2004), "El modelo gravitacional de comercio y el TLC entre Colombia y Estados Unidos", Working Papers Series, No. 27, Bogota, Foundation for Higher Education and Development.

Castro, M. (2010), "Diagnóstico y propuestas para el mejoramiento de los procesos de logística y aduana en la región de Centroamérica y Panamá", Project Documents (LCM.301), Santiago, Economic Commission for Latin America and the Caribbean (ECLAC).

CCS (Santiago Chamber of Commerce) (2016), "CCS: arancel efectivo de importación cerró 2015 en 1,2\%", Informe económico, Santiago, 29 February.

Cheng, I. and H. Wall (1999), "Controlling for heterogeneity in gravity models of trade", Working Paper, No. 1999-010A, St. Louis, St. Louis Federal Reserve Bank.

Cordero, M. (2014), "Logística y facilitación del comercio entre la Comunidad del Caribe y Centroamérica", Project Documents, No. 612 (LC/W.612), Santiago, Economic Commission for Latin America and the Caribbean (ECLAC).

Cortes, J. M. (2014), “¿Cuál es la razón de los altos costos de una exportación en Colombia?", Bogota, Nueva Granada Military University [online] http://repository.unimilitar.edu.co/bitstream/10654/11620/2/ Ensayo\%20final.pdf.

De Souza, M. J. P. and H. L. Burnquist (2011), "Impactos da facilitação de comércio: evidências do modelo gravitacional", Revista de Economia e Sociologia Rural, vol. 49, No. 4, Brasilia, Brazilian Society of Rural Economics and Sociology. 
Dingemans, A. and C. Ross (2012), "Free trade agreements in Latin America since 1990: an evaluation of export diversification", CEPAL Review, No. 108 (LC/G.2549-P), Santiago, Economic Commission for Latin America and the Caribbean (ECLAC).

DjanKov, S., C. Freund and C. Pham (2010), "Trading on time", The Review of Economics and Statistics, vol. 92, No. 1, Cambridge, Massachusetts, The MIT Press.

Durso, D. and H. Ochoa (2003), "Áreas monetarias óptimas: ¿está Latinoamérica cerca?" [online] http:// www.aaep.org.ar/anales/works/works2003/Durso_Ochoa.pdf.

Echeverría, M. (2007), "La facilitación del comercio en las negociaciones comerciales, multilaterales y bilaterales", Project Documents, No. 166 (LCM.166), Santiago, Economic Commission for Latin America and the Caribbean (ECLAC).

Egger, P. (2000), "A note on the proper econometric specification of the gravity equation", Economics Letters, vol. 66, No. 1, Amsterdam, Elsevier.

Eichengreen, B. and D. Irwin (1998), "The role of history in bilateral trade flows", The Regionalization of the World Economy, J. Frankel (ed.), Chicago, The University of Chicago Press.

Engman, M. (2005), "The economic impact of trade facilitation", OECD Trade Policy Papers, No. 21, Paris, Organization for Economic Cooperation and Development (OECD).

Florensa, L. and others (2013), "Acuerdos de integración económica en Latinoamérica: efectos sobre los márgenes de comercio", Revista de Economía, vol. 20, No. 1 [online] http://www.bvrie.gub.uy/local/File/ REVECO/2013/Florensa-Marquez-Ramos-Recalde-Barone.pdf.

Fuentes, N. A. and G. del Castillo (2012), "Reelaboración del modelo multisectorial dinámico para la planeación estratégica de la economía mexicana y simulación del programa de facilitación comercial”, Economía Mexicana. Nueva Época, vol. 21, No. 1, Mexico City, Economic Research and Teaching Centre.

García, J. (2013), "Alianza del Pacifico: ¿hacia dónde vamos?”, Agenda Internacional, vol. 20, No. 31, Lima, Institute for International Studies.

Giacalone, R. (2003), "CAN-MERCOSUR a la sombra del ALCA", Agroalimentaria, vol. 16, No. 16, Merida, University of the Andes.

Helble, M., B. Shepherd and J. Wilson (2007), Transparency and Trade Facilitation in the Asia Pacific: Estimating Gain from Reform, Washington, D.C., World Bank.

Helpman, E. and P. Krugman (1985), Market Structure and Foreign Trade: Increasing Returns, Imperfect Competition, and the International Economy, Cambridge, Massachusetts, The MIT Press.

Hernández, G. (2014), "Una revisión de los efectos del Tratado de Libre Comercio entre Colombia y Estados Unidos”, Lecturas de Economía, No. 80, Medellin, University of Antioquia.

Hesketh, D. (2010), "Weaknesses in the supply chain: who packed the box", World Customs Journal, vol. 4, No. 2 [online] http://worldcustomsjournal.org/Archives/Volume\%204,\%20Number\%202\%20(Sep\%20 2010)/02\%20Hesketh.pdf.

Hummels, D. (2007), "Transportation costs and international trade in the second era of globalization", Journal of Economic Perspectives, vol. 21, No. 3, Nashville, Tennessee, American Economic Association.

Iwanow, T. and C. Kirkpatrick (2009), "Trade facilitation and manufactured exports: is Africa different?", World Development, vol. 37, No. 6, Amsterdam, Elsevier.

(2007), "Trade facilitation, regulatory quality and export performance", Journal of International Development, vol. 19, No. 6, Wiley.

Izam, M. (2001), "Facilitación del comercio: un concepto urgente para un tema recurrente", International Trade series, No. 19 (LC/L.1680-P), Santiago, Economic Commission for Latin America and the Caribbean (ECLAC).

Jaén, A. (2010), "La UNCTAD y la integración regional en África", Nova Africa, No. 26, Barcelona.

Jean-François, A. and others (2007), Connecting to Compete 2007: Trade Logistics in the Global Economy, Washington, D.C., World Bank.

Jordaan, A. (2014), "The impact of trade facilitation factors on South Africa's exports to a selection of African countries”, Development Southern Africa, vol. 31, No. 4, Taylor \& Francis.

Kamil, H. and A. Ons (2003), "Formación de bloques comerciales regionales y determinantes del comercio bilateral: el caso del MERCOSUR", Working Paper, No. 2/02, Institute of Economics (IECON) [online] http://www.bvrie.gub.uy/local/File/JAE/2003/iees03j3230803.pdf.

LAIA (Latin American Integration Association) (2016), "Estadísticas de comercio exterior" [online] http:// consultawebv2.aladi.org/sicoexV2/jsf/comercio_exterior_item_arancelario.seam?cid=10711.

Lara, G. and I. Soloaga (2005), "Determinants of migration in México: gravity and spatial econometrics approaches", Working Paper, Puebla, University of the Americas. 
Lewer, J. and M. Sáenz (2004), "Efectos de la liberalización financiera sobre el comercio exterior: modelo gravitacional de Latinoamérica, 1995-99”, Estudios Económicos de Desarrollo Internacional, vol. 4, No. 2.

Linnemann, H. (1966), An Econometric Study of International Trade Flows, Amsterdam, North Holland.

López, L. and F. Fernando (2005), "La eficiencia portuaria colombiana en el contexto latinoamericano y sus efectos en el proceso de negociación con Estados Unidos” [online] https://www.researchgate.net/ publication/5006957_La_eficiencia_portuaria_colombiana_en_el_contexto_latinoamericano_y_sus_ efectos_en_el_proceso_de_negociacion_con_Estados_Unidos.

Márquez-Ramos, L. and others (2011), "'Special issue on Latin American research maritime networks' services structure and maritime trade", Networks and Spatial Economics, vol. 11, No. 3, Springer.

(2007), "Determinantes de los costes de transporte marítimos: el caso de las exportaciones españolas", Revista de Economía, No. 834.

Martínez-Zarzoso, I. and L. Márquez-Ramos (2008), "The effect of trade facilitation on sectoral trade", The BE Journal of Economic Analysis \& Policy, vol. 8, No. 1, De Gruyter.

Martínez-Zarzoso, I. and F. Nowak-Lehmann (2003), "Argumented gravity model: an empirical application to MERCOSUR-European Union trade flows”, Journal of Applied Economics, vol. 6, No. 2, Buenos Aires, CEMA University.

Martínez-Zarzoso, I. and C. Suárez-Burguet (2004), "Transport costs and trade: empirical evidence for Latin American imports from the European Union", Research Papers in International Business, No. 2-04, London, Center for International Business Studies.

Mátyás, L. (1997), "Proper econometric specification of the gravity model", The World Economy, vol. 20, No. 3, Wiley.

Meller, P., D. Poniachik and I. Zenteno (2012), "El impacto de China en América Latina: ¿desindustrialización y no diversificación de exportaciones?" [online] http://www.cieplan.cl/media/publicaciones/archivos/317/ Paper_El_Impacto_de_China_en_America_Latina_Desindustrializacion_y_no_Diversificacion_de_ Exportaciones.pdf.

Moïsé, E. and S. Sorescu (2013), "Trade facilitation indicators: the potential impact of trade facilitation on developing countries”, OECD Trade Policy Papers, No. 144, Paris, Organization for Economic Cooperation and Development (OECD).

Moreira, M. and others (2013), Too Far to Export: Domestic Transport Costs and Regional Export Disparities in Latin America and the Caribbean, Washington, D.C., Inter-American Development Bank (IDB).

Nicita, A., M. Olarreaga and I. Soloaga (2003), "The region as an export platform to the world? The case of MERCOSUR”, Cuadernos de Economía, vol. 40, No. 121, Santiago, Catholic University of Chile.

Nordas, H. K. and others (2006), "Logistics and time as a trade barrier", OECD Trade Policy Papers, No. 35, Paris, Organization for Economic Cooperation and Development (OECD).

OECD (Organization for Economic Cooperation and Development) (2003), "Trade facilitation reforms in the service of development" (TD/TC/WP(2003)11/FINAL), Paris.

Piani, G. and H. Kume (2000), "Fluxos bilaterais de comércio e blocos regionais: uma aplicação do modelo gravitacional”, Texto para Discussão, No. 749, Rio de Janeiro, Institute of Applied Economic Research.

Portugal-Pérez, A. and J. S. Wilson (2012), "Export performance and trade facilitation reform: hard and soft infrastructure”, World Development, vol. 40, No. 7, Amsterdam, Elsevier.

Pöyhönen, P. (1963), "A tentative model for the volume of trade between countries", Weltwirtschaftliches Archiv, No. 90, Springer.

Ramos Martínez, A. and others (2012), "Marcos teóricos para el análisis de las zonas de procesamiento de exportaciones en América Latina y el Caribe", Technical Notes, No. TN-432, Washington, D.C., Inter-American Development Bank (IDB).

Sá Porto, P. and C. Azzoni (2007), "How international integration affects the exports of Brazilian states", Revista de Economía Mundial, vol. 17, Huelva, World Economy Society.

Salgado, O. and P. Cea (2012), "Análisis de la conectividad externa de los puertos de Chile como un factor de competitividad”, Ingeniare. Revista Chilena de Ingeniería, vol. 20, No. 1, Arica, Tarapacá University.

Sandberg, H., J. Seale and T. Taylor (2006), "History, regionalism and CARICOM trade: a gravity model analysis", Journal of Development Studies, vol. 42, No. 5, Taylor \& Francis.

Sant'Anna, V. P. and M. J. P. de Souza (2014), "Uma análise do impacto da facilitação de comércio sobre as exportações brasileiras", Anais do XLI Encontro Nacional de Economia, No. 123, National Association of Centers for Post-graduation in Economics.

Santos-Silva, J. M. C. and S. Tenreyro (2006), "The log of gravity", Review of Economics and Statistics, vol. 88, No. 4, Cambridge, Massachusetts, The MIT Press. 
Serrano, R. and V. Pinilla (2008), "Comercio agrario latinoamericano, 1963-2000: aplicación de la ecuación gravitacional para flujos desagregados de comercio", Working Paper, No. 412, Savings Banks Foundation.

Servín, M. (2008), "Facilitando el comercio entre el Paraguay y la Unión Europea" [online] https://eulacfoundation. org/es/system/files/FACILITANDO\%20EL\%20COMERCIO\%20ENTRE\%2OPARAGUAY\%20Y\%20LA \%20UE.pdf.

Shepherd, B. (2016), "Did APEC's trade facilitation action plans deliver the goods?", Journal of Asian Economics, vol. 43, Amsterdam, Elsevier.

Shepherd, B. and J. S. Wilson (2006), "Road infrastructure in Europe and Central Asia: does network quality affect trade?", Policy Research Working Paper, No. 4104, Washington, D.C., World Bank.

Stark, C. (2011), "Agenda estratégica público-privada de cooperación regional para la facilitación del comercio y la inserción internacional: El Salvador y Guatemala", Project Documents (LC/W.374), Santiago, Economic Commission for Latin America and the Caribbean (ECLAC).

Tinbergen, J. (1962), Shaping the World Economy: Suggestions for an International Economic Policy, New York, Twentieth Century Fund.

Ueki, Y. (2015), "Trade cost and exportation: a comparison between enterprises in Southeast Asia and Latin America", Journal of Business Research, vol. 68, No. 4, Amsterdam, Elsevier.

Ueki, Y., M. Tsuji and R. Cárcamo (2005), "Tecnología de la información y las comunicaciones (TIC) para el fomento de las pymes exportadoras en América Latina y Asia oriental”, Project Documents (LC/W.33), Santiago, Economic Commission for Latin America and the Caribbean (ECLAC).

Valenzuela-Klagges, B. (2011), "Comercio y calidad institucional en el crecimiento económico del cono sur americano: cuestiones y desafíos”, Revista Pilquen-Sección Ciencias Sociales, No. 14, Viedma, National University of Comahue.

Valenzuela-Klagges, B. and L. E. Espinoza-Brito (2015), "Regionalismo latinoamericano y comercio bilateral", Revista Pilquen-Sección Ciencias Sociales, vol. 18, No. 2, Viedma, National University of Comahue.

Vallejo, H. and C. Aguilar (2004), "Integración regional y atracción de inversión extranjera directa: el caso de América Latina", Revista Desarrollo y Sociedad, Bogota, University of the Andes.

Wall, H. (2003), "NAFTA and the geography of North American trade", Review, St. Louis, St. Louis Federal Reserve Bank.

Wilson, N. (2007), "Examining the trade effect of certain customs and administrative procedures", OECD Trade Policy Papers, No. 42, Paris, Organization for Economic Cooperation and Development (OECD).

Wilson, J. S., C. Man and T. Otsuki (2003), "Trade facilitation and economic development: a new approach to quantifying the impact”, The World Bank Economic Review, vol. 17, No. 3, Oxford University Press.

World Bank (2013a), "Publications" [online] http://go.worldbank.org/2E22KVHM60. (2013b), "Trade and international integration" [online] http://go.worldbank.org/912Y1LS7E0. _(n/d), "World Bank Open Data" [online] https://data.worldbank.org/.

WTO/ITC/UNCTAD (World Trade Organization/International Trade Center/United Nations Conference on Trade and Development) (2015), World Tariff Profiles, 2015 (UNCTAD/WTO/2010), Geneva. (2010), World Tariff Profiles, 2010 (UNCTAD/WTO/2010), Geneva.

Zago de Azevedo, A. (2001), "What Has Been the Real Effect of MERCOSUR on Trade? A Gravity Model Approach", thesis [online] http://www8.ufrgs.br/ppge/pcientifica/2002_01.pdf.

Zaki, C. (2015), "How does trade facilitation affect international trade?", European Journal of Development Research, vol. 27, No. 1.

Zamora, A. and V. Sierens (2014), "Competitividad de los servicios logísticos del comercio exterior en la Cuenca del Pacífico", PORTES, Revista Mexicana de Estudios sobre la Cuenca del Pacífico, vol. 8, No. 15, Colima, University of Colima. 